\title{
Carbon and nitrogen resources available to kelp bed filter feeders in an upwelling environment
}

\author{
P. J. Fielding*, C. L. Davis \\ Department of Zoology, University of Cape Town, Rondebosch 7700, Cape Town, South Africa
}

\begin{abstract}
Environmental variables, and summer and winter particulate concentrations in the water column of a kelp bed in an upwelling region on the western Cape coast of South Africa, were measured daily to assess short-term fluctuations. There were significant differences between the summer and winter upwelling index, water temperature and wave height. Summer particulate carbon and nitrogen concentrations of $533 \mu \mathrm{g} \mathrm{l}^{-1}$ and $66 \mu \mathrm{g} \mathrm{l}^{-1}$ respectively were lower than winter levels of $764 \mu \mathrm{g} \mathrm{Cl}^{-1}$ and $79 \mu \mathrm{N} \mathrm{N}^{-1}$. However, summer upwelling events did not reduce particulate carbon and nitrogen to the very low levels that might be expected from previous studies of chlorophyll concentrations in the kelp bed. Large waves resulted in C:N ratios that were significantly higher in winter than in summer ( $p$ $<0.01$ ), and during continuous winter downwelling, a large proportion of the particulate material in the water column was of macrophyte rather than phytoplankton origin. In summer the carbon and nitrogen load was most highly correlated with temperature, while wind and wave size were the most important factors affecting particulate concentrations in winter. Mean particulate organic concentrations were 380 $\mu \mathrm{g} \mathrm{Cl^{-1 }}$ and $43 \mu \mathrm{g} \mathrm{N}^{-1}$ and these compare well with concentrations of $301 \mu \mathrm{g} \mathrm{Cl}^{-1}$ and $\left.41 \mu \mathrm{g} \mathrm{N}\right]^{-1}$ estimated from previous primary production studies. The estimated carbon demands of Choromytilus meridionalis and Aulacomya ater, 2 mussels that commonly occur in kelp beds on the west coast, could be met in winter and summer by the particulate organic component in the kelp bed water column. Particulate nitrogen resources probably meet most of the nitrogen requirements of the 2 mussels.
\end{abstract}

\section{INTRODUCTION}

The past decade has seen considerable research effort aimed at understanding the ecology of kelp bed systems, such as those on the west coast of South Africa. This work has been recently reviewed by Branch \& Griffiths (1988). Many of the data describing kelp bed communities were compiled for Oudekraal $\left(33^{\circ} 59^{\prime} \mathrm{S}, 18^{\circ} 21^{\prime} \mathrm{E}\right)$, a typical kelp bed system on the west coast of the Cape peninsula, South Africa, where an upwelling plume is a semi-permanent feature of the area during summer.

Newell \& Field (1983) concluded that the kelp bed consumer community depends on the utilization of carbon from phytoplankton and macrophyte detrital particles rather than via decomposer organisms, which could contribute only $9 \%$ of the estimated carbon requirements. They calculated that kelp detrital material and phytoplankton could meet $87.6 \%$ of the estimated nitrogen requirements of the consumer

\footnotetext{
- Present address: Oceanographic Research Institute, 2 West Street, Durban 4001, South Africa
}

organisms. Estimates of carbon and nitrogen resources available to the consumers were obtained indirectly from measurements of primary production and $\mathrm{C}: \mathrm{N}$ ratios of macrophytes and phytoplankton in the system (Newell et al. 1982, Newell \& Field 1983).

However, these may not be realistic estimates of the particulate food resources available to filter feeders. The system is subjected to pulses of upwelling generated by strong southeasterly winds in the spring and summer, followed by periods of downwelling (Andrews \& Cram 1969, Andrews \& Hutchings 1980, Field et al. 1980), which can result in rapid export and import of organic material and nutrients. Thus although phytoplankton and macrophyte production in the kelp bed can be measured, during conditions of upwelling and export, the particulate organic load in the water column may be too low to sustain filter feeders, while during downwelling and the import of organic material from the offshore region, the particulate load may be much higher than would be expected from production studies. Since the upwelling season lasts ca 8 mo of the year (Wulff \& Field 1983), it is possible that filter feeding organisms are nutritionally stressed by low levels of 
particulate material in the water column, in spite of very high primary production rates recorded in the area (Dieckmann 1980, Borchers \& Field 1981, Carter 1982). Furthermore, Carter (1982) expressed reservations about annual phytoplankton production estimates because of the accumulated errors in extrapolating daily and seasonal rates to annual rates in such a variable system. Brown \& Field (1985) described largescale diel fluctuations in phytoplankton productivity over $4 \mathrm{~d}$ periods at different times of the year.

Previous measurements of the concentrations of particulate material present in the kelp bed water column (Field et al. 1980, Stuart 1982, Stuart \& Klumpp 1984, Seiderer \& Newell 1985), which might provide a better indication of the food available to filter feeders in the system, have generally been carried out over short periods and at widely spaced intervals. In view of this an intensive sampling programme was carried out for 2 mo in summer and $1 \mathrm{mo}$ in winter, in order to characterize short-term fluctuations in a highly variable system. The object of this study was to determine the effect of physical parameters on particulate load in the water column, to assess the particulate carbon and nitrogen resources available to the filter feeding community in a kelp bed system, and to determine whether these food resources balanced the requirements of 2 mussel species that commonly occur in kelp beds on the western Cape coast. A comparison could then be made between food resources estimated from primary production studies and those actually measured in the water column.

\section{MATERIALS AND METHODS}

Sampling procedure: particulate carbon and nitrogen. Water samples were collected daily at 08:00 h from the shore at Oudekraal for $52 \mathrm{~d}$ in November/ December 1984, which is defined as the main spring/ summer upwelling season (Andrews \& Hutchings 1980), and $31 \mathrm{~d}$ in June/July 1985 (winter). The water was prefiltered with a $200 \mu \mathrm{m}$ mesh, and a measured volume of between 100 and $900 \mathrm{ml}$, depending on particulate load, was immediately filtered through a pre-ashed $\left(400^{\circ} \mathrm{C}\right.$ for $\left.6 \mathrm{~h}\right) 25 \mathrm{~mm}$ Whatman $\mathrm{GF} / \mathrm{F}$ filter by gentle hand-pump filtration. Filters were oven-dried at $50^{\circ} \mathrm{C}$ for $3 \mathrm{~d}$ and combusted in a Heraeus CHNMikro Universal combustion analyser calibrated with cyclohexanone (Monar 1972). Unused, pre-ashed filters were analysed as carbon and nitrogen blanks. The net carbon and nitrogen values for each filter paper were expressed as $\mu \mathrm{g} \mathrm{l}^{-1}$

Environmental parameters. At the time of sample collection sea temperature was measured and a visual estimate made of swell height. Average daily wind speed and direction at a height $10 \mathrm{~m}$ above the sea surface were obtained from the Koeberg weather station about $10 \mathrm{~km}$ north of the sample site. The longshore wind component was calculated according to the upwelling index, $V t=U(\operatorname{Cos} \theta-160)$, where $U=$ wind speed, $\theta=$ wind direction, and 160 is the orientation of the Cape west coast (Jury 1980). These were plotted on a scale of +10 to -10 where 0 represents the boundary between upwelling $(+)$ and downwelling $(-)$. Multiple stepwise correlation analysis was performed using Statpro (Wadworths), to assess the influence of temperature, wind and swell on particulate carbon and nitrogen levels in the water column. Analysis was terminated when no additional variable was correlated below the 0.05 significance level.

C:N ratios. To calculate ambient $C: N$ ratios for suspended particles, the material accumulating on the $0.45 \mu \mathrm{m}$ intake filter of the Sea Fisheries Research Institute aquarium pump, which draws water from the inshore edge at a point $5 \mathrm{~km}$ north of Oudekraal, was backwashed into a container, filtered through a 200 $\mu \mathrm{m}$ mesh and the contents centrifuged $(7000 \times \mathrm{g}$ for $15 \mathrm{~min}$ ) to precipitate organic matter. The precipitate was lyophilized and 3 weighed samples were combusted in the CHN analyser. This procedure was repeated twice in summer and once in winter. This material was considered to be a mixture of phytoplankton and detritus. During the summer sampling, tips of mature kelp fronds were lyophilized, pooled, puiverized and 3 weighed samples were subjected to CHN analysis.

\section{RESULTS AND DISCUSSION}

Summer and winter means of all the variables measured are summarized in Table 1.

\section{Temperature and wind}

The upwelling index shows that during summer, the Oudekraal area was charactenzed by strong southeasterly winds over periods of ca $5 \mathrm{~d}$, which caused pulsed upwelling of cold water into the system (Fig. 1A, B, hatched areas). The drop in sea temperature generally lagged the wind factor by $1 \mathrm{~d}$. When southerly winds relaxed or changed to onshore northerly/northwesterly winds, stabilization of the water column or downwelling occurred, accompanied by a rise in water temperature. In winter, onshore northerly winds prevailed, little upwelling occurred and sea temperatures remained fairly stable. This conforms with the findings of Andrews \& Hutchings (1980), Dieckmann (1980), Field et al (1980), Carter (1982), and Brown \& Field $(1985,1986)$. 
Table 1 Summary of summer and winter means of all varlables measured. Significant seasonal differences are also shown

\begin{tabular}{|c|c|c|c|}
\hline Variable & Summer $( \pm S D)$ & Winter $( \pm S D)$ & $\begin{array}{c}\text { Significant } \\
\text { difference }(t \text {-test })\end{array}$ \\
\hline Temperature $\left({ }^{\circ} \mathrm{C}\right)$ & $12.1( \pm 1.7)$ & $15.2( \pm 1.0)$ & $+(p<0.01)$ \\
\hline Wind (Upwelling Index) & $2.45( \pm 3.76)$ & $-0.93( \pm 3.29)$ & $+(p<0.01)$ \\
\hline Swell height (m) & $0.49( \pm 0.66)$ & $1.25( \pm 0.92)$ & $+(p<0.01)$ \\
\hline Carbon $\left(\mu g 1^{-1}\right)$ & $533( \pm 242)$ & $764( \pm 425)$ & $+(p<0.01)$ \\
\hline Nitrogen ( $\left.\mu \mathrm{g} \perp^{-1}\right)$ & $66( \pm 29)$ & $79( \pm 43)$ & $-(p>0.05)$ \\
\hline$C: N$ ratio & $8.14( \pm 1.6)$ & $9.90( \pm 2.08)$ & $+(p<0.01)$ \\
\hline
\end{tabular}

The second pulse of upwelling (Days 11 to 16) was not strongly marked by a temperature drop because of solar heating of the water, but high nitrate concentrations recorded in water samples taken during this period indicated that upwelling had occurred (Muir 1986). Although the prevailing winds were northwesterly in winter, on Days 6 to 8 strong southeasterly winds blew and a sharp drop in temperature occurred (Fig. 1A, B). Thus during both study periods sea temperatures were closely associated with the wind regime. Mean sea temperatures were significantly lower in summer than in winter (Table 1, $t$-test, $p<0.01$ ).

\section{Wave action}

Strong northwesterly winds generated large swells (Fig. 1A, C) producing considerable turbulence in the inshore area. The largest swells recorded during the sampling period were $3.5 \mathrm{~m}$, although heights of 5 to $7 \mathrm{~m}$ have been recorded by Velimirov et al. (1977) and Field et al. (1980). In summer wave action was much reduced, and long periods of calm seas occurred (Fig. 1C), although even in summer, northwesterly winds rapidly increased swell size (see Days 3 to 4,25 to 26. 34 to 37 and 49 to 53 in Fig. 1A, C). Mean winter swell height was significantly greater than that of summer (Table 1, t-test, $p<0.01$ ).

\section{Particulate load}

Previous studies have shown that particulate and chlorophyll concentrations decline to very low levels during upwelling when offshore winds move surface waters away from the coast (Field et al. 1980, Carter 1982, Brown 1984, Brown \& Field 1986). These data were calculated from water samples taken at the outer edge of the Oudekraal kelp beds. Fig. 1D, E shows that, at the inshore edge during the main upwelling season. even though strong southeasterly winds blew at regular intervals (Fig. 1A), levels of particulate carbon and nitrogen in the water column, although lower in sum- mer than in winter (Table 1), did not decline to the low levels reported slightly further offshore. Mean summer chlorophyll a concentration was $1.64 \mu \mathrm{g} \mathrm{l^{-1 }}$ (Fielding 1987 ) and was seldom reduced to the very low values recorded offshore in newly upwelled water (Andrews \& Hutchings 1980, Barlow 1982, Brown \& Field 1986, Lucas et al. 1986). In the inshore region, because of the sheltering effect of the mountainous Cape Peninsula and increasing bottom drag, rates of upwelling are lower than further offshore (Andrews \& Hutchings 1980), and the southeasterly summer winds may therefore not be overridingly important in regulating the food available to inshore primary consumers. Field et al. (1980) have shown that during upwelling, currents in the water column were offshore at the surface and onshore on the bottom, and bottom currents reached speeds of $10 \mathrm{~cm} \mathrm{~s}^{-1}$ or more during active upwelling. These onshore bottom currents may resuspend enough material to maintain particulate carbon and nitrogen levels in the nearshore water column (Fig. 1D, E).

It has also been stated (Field et al. 1980, Newell et al. 1982) that there is a large export of organic matter by wind-driven water currents in the upwelling season during rough weather, because of the fragmentation of kelp and the resuspension of bottom material. Fig. 1C demonstrates that in the 1984/1985 upwelling season, large waves were not a common phenomenon, and on only 3 d out of 54 was the swell height $>2 \mathrm{~m}$. Thus the importance of resuspension and export of organic matter by the combined action of waves and offshore winds should not be overestimated in the context of kelp bed dynamics. In winter, onshore winds may result in a net import of offshore detritus and phytoplankton to the inshore region but, more importantly, the large swells generated by these winds greatly increase kelp plant erosion and destruction, as well as the resuspension of particles that have sunk to the sea bed (Field et al. 1980).

\section{Carbon}

With the import of detrital/phytoplankton particles by onshore winds and the increased erosion and des- 

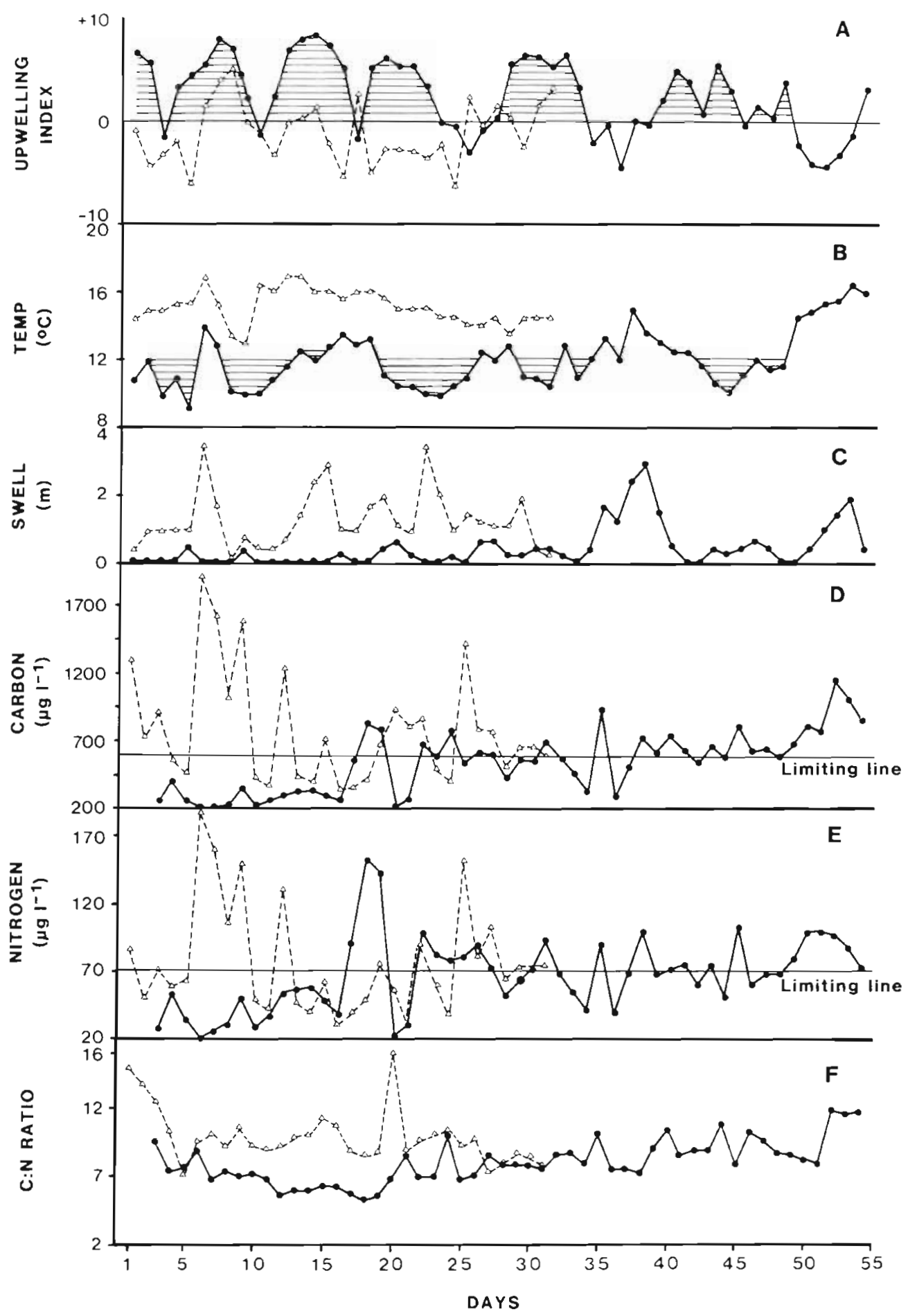

Fig. 1. Summer $(\bullet)$ and winter $(\Delta--\Delta)$ variables in the kelp bed at Oudekraal Cape Peninsula, South Africa. Hatched areas indicate periods of southeasterly winds which cause upwelling of cold water. The upwelling index is the relationship between wind speed, direction, and the orientation of the coastline isee 'Materials and methods'). Limiting line is the particulate concentration above which kelp bed filter feeders are able to mantain a positive ener gy balance

truction of kelp by strong wave action, higher particulate carbon levels might be expected in winter than in summer, and this was shown to occur (Fig. 1D). The seasonal difference in particulate carbon concentrations (Table 1 ) was significant ( $t$-test, $p<0.01$ ), and these values are comparable with those reported by Stuart \& Klumpp (1984) (416 $\mu \mathrm{g} \mathrm{Cl}^{-1}$ ) and Seiderer \&
Newell (1985) (307 to $450 \mu \mathrm{g} \mathrm{C}^{-1}$ ). Stepwise multiple correlation analysis showed that summer particulate carbon concentrations were correlated with wind and temperature, whereas in winter, wind and swell were the most important factors affecting carbon levels (Table 2). Carbon was negatively correlated with wind in summer, since the prevailing offshore wind removed 
Table 2. Independent parameters influencing water column particulate carbon and nitrogen loads as determined by stepwise multiple correlation analyses $(p<0.05)$

\begin{tabular}{|c|c|c|c|}
\hline $\begin{array}{l}\text { Dependent } \\
\text { variable }\end{array}$ & $\begin{array}{c}\text { Independent } \\
\text { variable }\end{array}$ & Sign & Cumulative $r^{2}$ \\
\hline \multirow[t]{2}{*}{$\mu \mathrm{g} \mathrm{Cl} l^{-1}$ summer } & Temperature & + & 0.197 \\
\hline & Wind & - & 0.288 \\
\hline$\mu \mathrm{g} \mathrm{N} d^{-1}$ summer & Temperature & + & 0.079 \\
\hline \multirow[t]{2}{*}{$\mu \mathrm{g} \mathrm{C} \mathrm{l}^{-1}$ winter } & Wind & + & 0.205 \\
\hline & Swell & + & 0.292 \\
\hline \multirow[t]{2}{*}{$\mu \mathrm{g} \mathrm{N} l^{-1}$ winter } & Wind & + & 0.212 \\
\hline & Swell & + & 0.303 \\
\hline
\end{tabular}

particulates from the area. In winter the wind/carbon correlation was positive since the onshore northwesterly winds imported particulates and generated strong wave action which increased kelp frond erosion. Field et al. (1980) also recorded increases in particulate matter with increased swell height.

\section{Nitrogen}

Changes in particulate nitrogen levels in the water were very closely linked with fluctuations in particulate carbon levels (Fig. 1D, E). Mean daily particulate nitrogen concentration was lower in summer than in winter (Table 1) but the difference was not significant ( $t$-test, $p>0.05$ ). Particulate nitrogen was significantly correlated with temperature in summer, and with wind and swell in winter (Table 2).

\section{$C: N$ ratio}

Although both carbon and nitrogen concentrations fluctuated synchronously, Fig. $1 F$ shows that $C$ : N ratios of the particulate load in the water column were significantly higher ( $t$-test, $p<0.01)$ in winter $(9.90 \pm 2.08$ $\mathrm{SD})$ than in summer $(8.14 \pm 1.6 \mathrm{SD})$. The mean $\mathrm{C}: \mathrm{N}$ ratio of 3 samples of Laminaria pallida frond tips was 17.28 ( $\pm 0.01 \mathrm{SD}$ ) while that of the phytoplankton/ detritus from the aquarium pump filter was 7.80 ( \pm $0.67 \mathrm{SD}$ ). A seasonal increase in particulate $\mathrm{C}: \mathrm{N}$ ratios was therefore probably a result of increased input of kelp fragments resulting from strong wave action in winter (Fig. 1C), rather than phytoplankton/detritus, or phytoplankton, which has a C:N ratio of between 5.80 and 7.30 (Bishop et al. 1978, Seiderer et al. 1984, Seiderer \& Newell 1985, Branch \& Griffiths 1988).

The model proposed by Wulff \& Field (1983) of trophic relationships in the kelp bed at Oudekraal predicts that, under continuous downwelling conditions, phytoplankton from the pelagic zone enters the kelp bed and may form up to $93 \%$ of the food available to filter feeders. In winter, onshore winds and downwelling occurred most of the time (Fig. 1A), and on the basis of the model, a high proportion of phytoplankton would therefore have been expected in the particulates in the water column. A C:N ratio of 9.90 in winter implies that during continuous downwelling, a large proportion of the particulate matter is of macrophyte origin, particularly as Laminaria frond $\mathrm{C}: \mathrm{N}$ ratios are only 11.70 in winter (Dieckmann 1978). Table 2 shows that swell size was significantly correlated with particulate carbon and nitrogen levels in winter, and therefore should not be disregarded as a parameter in a model of kelp bed nutrient fluxes.

\section{Comparison of measured particulate concentration with estimates of primary production}

Although the kelp bed system is not closed and there is considerable water turnover, particularly during times of strong upwelling and downwelling, a comparison can be made between the resources available for filter feeder consumption estimated from primary production, and those actually measured in the system. Energy balance in the various trophic levels of the kelp bed community at Oudekraal has been reviewed by Newell \& Field (1983). They calculated that production of particulate organic matter by macrophytes and phytoplankton amounted to $1100 \mathrm{~g} \mathrm{C} \mathrm{m}^{-2} \mathrm{yr}^{-1}$ while particulate nitrogen production was $150 \mathrm{~g} \mathrm{~N} \mathrm{~m}^{-2} \mathrm{yr}^{-1}$. The average depth of the kelp bed is $10 \mathrm{~m}$ (Field et al. 1980). Thus production would be $110 \mathrm{mg} \mathrm{Cl}^{-1} \mathrm{yr}^{-1}$ and $15 \mathrm{mg} \mathrm{N} l^{-1} \mathrm{yr}^{-1}$. Although particulate carbon and nitrogen concentrations fluctuate somewhat, it can reasonably be assumed for the purposes of this comparison that macrophyte-derived particulates and phytoplankton production enter the water column at a regular rate throughout the year. Therefore, according to their estimates, $301 \mu \mathrm{g} \mathrm{C} l^{-1}$ and $41 \mu \mathrm{g} \mathrm{N} \mathrm{l}^{-1}$ would enter the system every day.

The present study showed that particulate carbon in the water column averaged $533 \mu \mathrm{g} \mathrm{Cl}^{-1}$ in summer and $764 \mu \mathrm{g} \mathrm{C} \mathrm{l}^{-1}$ in winter, but this comprises some inorganic component. This was examined in detail by Field et al. (1980), who sampled the particulate fraction at Oudekraal over $24 \mathrm{~d}$ that included calm and very rough weather. From their study the percentage organic matter present in water samples taken during periods of different swell heights may be calculated. At $<1 \mathrm{~m}$ and 1 to $2 \mathrm{~m}$ swell height, the organic fraction was $62 \%$ and $64 \%$ respectively of the particulate load, while at $>2 \mathrm{~m}$ swell height there was a decline to $53 \%$ organic matter. Thus a mean value of $63 \%$ organic matter for swell conditions of $2 \mathrm{~m}$ or less and $53 \%$ for $>2 \mathrm{~m}$ swell 
conditions was used. Mean daily summer particulate organic carbon and nitrogen levels were therefore 335 $\mu \mathrm{g} \mathrm{C} l^{-1}$ and $41 \mu \mathrm{g} \mathrm{N}^{-1}$, and mean winter levels were $469 \mu \mathrm{g} \mathrm{C} \mathrm{I}^{-1}$ and $48 \mu \mathrm{g} \mathrm{N} \mathrm{I^{-1 }}$ Since the upwelling season (summer) prevails for $8 \mathrm{mo}$ of the year and the winter season for 4 mo (Wulff \& Field 1983), the daily average over a year would be $380 \mu \mathrm{C} \mathrm{Cl}^{-1}$ and $43 \mu \mathrm{g} \mathrm{N}$ $1^{-1}$. These values agree well with those calculated from production studies.

\section{Potential yield of particulates for consumers}

Between 80 and $99 \%$ of particles in the water column have been shown to be in the size range 5 to $20 \mu \mathrm{m}$ during upwelling and downwelling (Field et al. 1980, Stuart \& Klumpp 1984), and are therefore available to the kelp bed filter feeders as food. Thus data on particulate carbon and nitrogen levels in the water column may be used to compare potential yield from particulate resources with the estimated carbon and nitrogen requirements of Choromytilus meridionalis and Aulacomya ater, 2 mussel species that occur in kelp beds on the Cape west coast, although such estimations are relatively crude. Many factors such as changes in ingestion rates and gut residence times with season or particulate load, environmental factors, varying rates of protein synthesis and rhythms of digestion, absorption and excretion may play a part in regulating mussel nutrient acquisition (Bayne \& Newell 1983, Hawkins et àl. 1983, Hawkins \& Bayne 1984, 1985, Widdows et al. 1984, Hawkins 1985). Processes that occur at the benthic boundary layer may also at times modify the availability of particulate material to suspension feeders (Wildish \& Kristmanson 1984, Frechette \& Bourget 1985). The calculation of the potential yield of particulates to consumers is shown in Tables 3 and 4 .

There are numerous data on clearance rates, absorption efficiencies and respiration rates of the mussels Choromytilus meridionalis and Aulacomya ater (Griffiths 1980a, b, Stuart 1982, Stuart et al. 1982, Stuart \& Klumpp 1984). Values given in Tables 3 and 4 for clearance and respiration rates are for feeding specimens at particulate loads approximating those of the kelp beds (Griffiths 1980a, Stuart \& Klumpp 1984). Winter respiration rates have been calculated assuming that a $Q_{10}$ of 1.69 (Griffiths 1980a) applies to both species of mussel. Clearance rates of mussels such as $C$. meridionalis and Mytilus edulis do not change with seasonal changes in temperature (Widdows 1978, Widdows et al. 1979, Griffiths 1980a), thus clearance rates for summer and winter are the same. Griffiths (1980a) reported that respiration comprises $74 \%$ of the absorbed ration in $C$. meridionalis, thus the carbon equivalent of the absorbed ration can be calculated from Respiration $\times 1.35$. Potential yield was obtained from the product of the concentration of the resource, which appears to be always available, and the clearance rate.

The absorbed ration has been calculated from literature estimates of absorption efficiencies. Stuart et al. (1982) have shown that kelp debris is absorbed with an efficiency of 0.50 by the mussel Aulacomya ater, while Choromytilus meridionalis had an absorption efficiency of 0.40 when feeding on natural detritus (Griffiths 1980b).

Table 3. Aulacomya ater and Choromytilus meridionalis. Carbon requirements of mussels compared with potential carbon absorbed from the organic particulate fraction in the water column. Carbon requirements are calculated from respiration rates (Griffiths 1980a, Stuart \& Klumpp 1984) $\times 1.35$, using a conversion of $1 \mathrm{ml} \mathrm{O} 2=530 \mu \mathrm{g}$ (Hawkins \& Bayne 1985). Potential yield is obtained by multiplying clearance rate by organic carbon available. Carbon absorbed is the product of absorption efficiency and potential yield. Clearance rates and oxygen consumption values are for feeding individuals at $12^{\circ} \mathrm{C}$ (summer) and $15^{\circ} \mathrm{C}$ (winter) assuming a $Q_{10}$ of 1.69 (Griffiths 1980a) for respiration.

\begin{tabular}{|c|c|c|c|}
\hline Parameter & Season & A. ater & C. meridionalis \\
\hline Oxygen consumption & Summer & 300 & 430 \\
\hline$\left(\mu \mathrm{I} \mathrm{O}_{2} \mathrm{~h}^{-1} \mathrm{~g}^{-1}\right)$ & Winter & 362 & 519 \\
\hline Carbon required & Summer & 215 & 308 \\
\hline$\left(\mu \mathrm{g} \mathrm{h}^{-1} \mathrm{~g}^{-1}\right)$ & Winter & 259 & 371 \\
\hline $\begin{array}{l}\text { Clearance rate } \\
\left(1 \mathrm{~h}^{-1} \mathrm{~g}^{-1}\right)\end{array}$ & & 1.82 & 5.37 \\
\hline Organic carbon available & Summer & 335 & 335 \\
\hline$\left(\mu \mathrm{g} \mathrm{l}^{-1}\right)$ & Winter & 469 & 469 \\
\hline Potential yield & Summer & 610 & 1.799 \\
\hline$\left(\mu g h^{-1} g^{-1}\right)$ & Winter & 854 & 2519 \\
\hline Absorption efficiency & & 0.50 & 0.40 \\
\hline Carbon absorbed & Summer & 305 & 720 \\
\hline$\left(\mu \mathrm{g} \mathrm{h}^{-1} \mathrm{~g}^{-1}\right)$ & Winter & 427 & 1008 \\
\hline \multirow[t]{2}{*}{$\%$ of requirements } & Summer & $142 \%$ & $234 \%$ \\
\hline & Winter & $165 \%$ & $272 \%$ \\
\hline
\end{tabular}


Table 4. Aulacomya ater and Choromytilus meridionalis. Nitrogen requirements of mussels compared with potential nitrogen absorbed from the organic particulate fraction in the water column. Nitrogen requirements are calculated from absorbed ration $=$ $1.35 \times$ Respiration (Griffiths 1980a) recalculated as $\mu g \mathrm{~h}^{-1}$ and an $\mathrm{O}: \mathrm{N}$ ratio of 11 (Hawkins 1983). Potential yield is obtained by multiplying clearance rate by organic nitrogen available. Nitrogen absorbed is the product of absorption efficiency and potential yield. Clearance rates and oxygen consumption values are for feeding individuals at $12^{\circ} \mathrm{C}$ (summer) and $15^{\circ} \mathrm{C}$ (winter), assuming a $Q_{10}$ of 1.69 (Griffiths 1980a) for respiration

\begin{tabular}{|c|c|c|c|}
\hline Parameter & Season & A. ater & C. meridionalis \\
\hline Oxygen consumption & Summer & 300 & 430 \\
\hline$\left(\mu \mathrm{I} \mathrm{O}_{2} \mathrm{~h}^{-1} \mathrm{~g}^{-1}\right)$ & Winter & 362 & 519 \\
\hline Nitrogen required & Summer & 53 & 75 \\
\hline$\left(\mu g h^{-1} g^{-1}\right)$ & Winter & 64 & 91 \\
\hline$\left(1 \mathrm{~h}^{-1} \mathrm{~g}^{-1}\right)$ & & 1.82 & 5.37 \\
\hline Organic nitrogen available & Summer & 41 & 41 \\
\hline$\left(\mu \mathrm{g} \mathrm{l}^{-1}\right)$ & Winter & 48 & 48 \\
\hline Potential yield & Summer & 75 & 220 \\
\hline$\left(\mu \mathrm{g} \mathrm{h}^{-1} \mathrm{~g}^{-1}\right)$ & Winter & 87 & 258 \\
\hline Absorption efficiency & & 0.50 & 0.40 \\
\hline Nitrogen absorbed & Summer & 38 & 88 \\
\hline$\left(\mu \mathrm{g} \mathrm{h}^{-1} \mathrm{~g}^{-1}\right)$ & Winter & 44 & 103 \\
\hline \multirow[t]{2}{*}{$\%$ of requirements } & Summer & $72 \%$ & $117 \%$ \\
\hline & Winter & $69 \%$ & $113 \%$ \\
\hline
\end{tabular}

Table 3 shows that the carbon demands of Choromytilus meridionalis and Aulacomya ater could easily be met in summer and winter by the organic particulate component in the water column, despite summer upwelling events which reduce chlorophyll concentrations to low levels (Field et al. 1980, Carter 1982, Brown 1984, Brown \& Field 1986). Thus there is considerable scope for growth and reproduction, particularly for $C$. meridionalis. A. ater grows very much more slowly than C. meridionalis (Griffiths 1977. Griffiths \& King 1979) and it is of interest that more than twice the carbon requirements of $C$. meridionalis can be met by the particulate fraction compared with 1.42 to 1.65 times the requirements of $A$. ater. It is possible that the concentration of particulate material close inshore does not represent the true particulate concentration available to filter feeders in deeper waters, since these animals are continually removing particles from the water column. Field et al. (1980) recorded lower concentrations of particulate organic material inshore than in the deeper waters overlying the kelp bed filter feeding population. However, differences were small $(<10 \%)$, and there was no difference between surface and bottom particulate concentrations either inshore or further offshore. Stuart \& Klumpp (1984) recorded average annual concentrations of $416 \mu \mathrm{g} \mathrm{Cl}^{-1}$ and $62 \mu \mathrm{g} \mathrm{N}$ $\mathrm{l}^{-1}$ in the water adjacent to a bed of suspension feeders at Oudekraal. These values compare favourably with mean values of $380 \mu \mathrm{g} \mathrm{C}{ }^{-1}$ and $43 \mu \mathrm{g} \mathrm{N}{ }^{-1}$ estimated in this study. Table 3 therefore probably provides a reasonable estimate of the carbon resource available to the mussels.
Little is known about the nitrogen requirements of South African mussels. Nitrogen requirements of Mytilus edulis vary with season, growth and reproductive condition (Bayne \& Widdows 1978, Hawkins 1985, Hawkins \& Bayne 1985), and caution must be exercised when considering nitrogen requirements that have not been experimentally determined. However, an estimate of the maximum nitrogen requirements of these animals can be made. Hawkins (1983) showed that for M. edulis, seasonally varying nitrogen losses resulted in O:N ratios of between 11 and 108. Maximum nitrogen ingestion requirements would result from an $O: N$ ratio of 11 (see also Bayne 1973, Widdows et al. 1984). Calculation of the nitrogen requirements of Choromytilus meridionalis and Aulacomya ater from respiration rates and an $\mathrm{O}: \mathrm{N}$ ratio of 11 is shown in Table 4. It is likely that the nitrogen available from the particulate component in the kelp bed water column can meet much of the nitrogen ingestion requirements of both species of mussel, since nitrogen demand estimated in Table 4 is probably close to the maximum. Average $\mathrm{O}: \mathrm{N}$ ratios for $M$. edulis were between 20 and 46 (Hawkins 1983, Widdows et al. 1984) and a ratio of 22 would reduce the nitrogen requirements calculated in Table 4 by $50 \%$.

Bacteria may further contribute to the nitrogen budget of Choromytilus meridionalis and Aulacomya ater, although the importance of nitrogen-rich bacteria in mussel nutrition is not clear. Bacteria in the kelp bed water column contribute a total of $99 \mathrm{~g} \mathrm{~N} \mathrm{~m}^{-2} \mathrm{yr}^{-1}$ (Newell \& Field 1983). Muir et al. (1986) have shown that bacteria can be filtered from the water column by $C$. 
meridionalis. However, Stuart \& Klumpp (1984) and Lucas et al. (1987) showed that although mussels can remove bacteria from the water, the filtration is not efficient. The crystalline style of $C$. meridionalis contains enzymes capable of lysing water column bacteria (Seiderer et al. 1984, Muir et al. 1986), and bacteria may therefore assist to a limited extent in contributing to the nitrogen budget of this species. It would be of interest to determine whether $A$ ater can produce bacteriolytic enzymes to a greater extent than $C$. meridionalis.

Energy balances for various kelp bed filter feeders and for the kelp bed as a whole have been described before (Newell et al. 1982, Stuart 1982, Newell \& Field 1983, Klumpp 1984, Stuart \& Klumpp 1984, Seiderer \& Newell 1985). In all cases the animals described have been shown to maintain a positive energy balance using the particulate resources available. Kelp bed filter feeder requirements are $1297 \mathrm{~g} \mathrm{C} \mathrm{m}^{-2} \mathrm{yr}^{-1}$ and $160 \mathrm{~g} \mathrm{~N} \mathrm{~m}^{-2} \mathrm{yr}^{-1}$ (Newell \& Field 1983). On a daily basis this amounts to $3.55 \mathrm{~g} \mathrm{C} \mathrm{m}^{-2} \mathrm{~d}^{-1}$ and $0.44 \mathrm{~g} \mathrm{~N} \mathrm{~m}^{-2}$ $\mathrm{d}^{-1}$. Since the average depth of the kelp bed is $10 \mathrm{~m}$

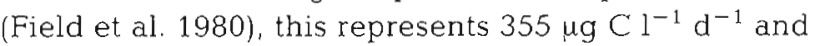
$44 \mu \mathrm{g} \mathrm{N} \mathrm{N}^{-1} \mathrm{~d}^{-1}$. If the organic fraction comprises ca $60 \%$ of the particulate load then filter feeders require a daily mean of $592 \mu \mathrm{g} \mathrm{Cl}^{-1}$ and $73 \mu \mathrm{g} \mathrm{N}^{-1}$ to maintain a positive energy balance. This is shown as the limiting line in Fig. 1D, E. Assuming that consumers are feeding on water of mean particle concentration (Widdows et al. 1979, Field et al. 1980), it can be seen that periodically, particularly in summer, the filter feeder carbon and nitrogen requirements may be undersupplied. It is of interest that for the common kelp bed filter feeders such as Choromytilus meridionalis, Aulacomya ater and Pyura stolonifera, clearance and respiration rates and assimilation efficiencies are independent of food concentration (Griffiths 1980b, Stuart 1982, Klumpp 1984). Ingested and assimilated ration continues to rise with particulate concentration and the animals are therefore adapted to maximise energetic gain during times of high particulate concentrations in order to store reserves for the times when food may be limited.

Acknowledgements. We thank Dr L. J. Seiderer for help with the sampling, Mr $\Upsilon$ Hempsted for his assistance with the CHN analyses, and Dr $M$. Lucas for critically reading the manuscript. Financial assistance was provided by the Electricity Supply Commission for P. J. F and by the South African National Council for Oceanographic Research for C. L. D.

\section{LITERATURE CITED}

Andrews, W. R. H., Cram, D. L. (1969). Combined serial shipboard upwelling study in the Benguela current. Nature, Lond. 24: 902-904

Andrews, W R. H., Hutchings, L. (1980). Upwelling in the southern Benguela current. Prog. Oceanogr 9: 1-81
Barlow, R. G. (1982). Phytoplankton ecology in the southern Benguela current. I. Biochemical composition. J. exp. mar Biol. Ecol. 63: 209-227

Bayne. B. L. (1973). Aspects of the metabolism of Mytilus edulis during starvation. Neth. J. Sea Res. 7: 399-410

Bayne, B. L. Widdows, J. (1978). The physiological ecology of two populations of Mytilus edulis L. Oecologia (Berl.) $37(2): 137-162$

Bayne, B. L, Newell, R. C. (1983). Physiological energetics of marine molluscs. In: Salueddin, A. S. M., Wilbur, K. M (eds.) The Mollusca, Vol 4, Physiology, Part I. Academic Press, New York, p. 407-515

Bishop, J. K. B., Ketten, D. R., Edmond, J. M. (1978). The chemistry, biology, and vertical flux of particulate matter from the upper $400 \mathrm{~m}$ of the Cape Basin in the Southeast Atlantic ocean. Deep Sea Res. 25: 1121-1161

Borchers, P., Field, J. G. (1981). The effect of kelp shading on phytoplankton production. Botanica mar. 24: 89-91

Branch, G. M., Griffiths, C. L. (1988). The Benguela ecosystem Part V The coastal zone. Oceanogr. mar. Biol. A. Rev. 26 395-486

Brown, P. C. (1984). Primary production at two contrasting nearshore sites in the Southern Benguela upwelling region, 1977-1979. S. Afr. J. mar. Sci. 2: 205-227

Brown, P. C., Field, J. G. (1985). Diel variation in production rates of natural phytoplankton populations in the southern Benguela upwelling regions. Botanica mar 28: 201-208

Brown, P. C., Field, J. G. (1986). Factors limiting phytoplankton production in a nearshore upwelling area. J. Plankton Res. 8(1): 55-68

Carter, R. A. (1.982). Phytoplankton biomass and production in a southern Benguela kelp bed system. Mar Ecol. Prog. Ser 8: 9-14

Dieckmann, G. S. (1978). Aspects of growth and production of Laminaria pallida (Grev.) off the Cape Peninsula. M. Sc. thesis. University of Cape Town, South Africa

Dieckmann, G.S. (1980). Aspects of the ecology of Laminaria pallida (Grev.) J. Ag off the Cape Peninsula (South Africa). Botanica mar 23: 579-585

Field, J. G., Griffiths, C. L., Linley, E. A. (1980). Upwelling in a nearshore marine ecosystem and its biological implications. Estuar. coast. mar. Sci. 11: 133-150

Fielding, P. J. (1987). Relation of crystalline style function to tood availabiljty and environmental conditions in South African mussels. Ph. D, thesis. University of Cape Town, South Africa

Frechette, M., Bourget, E. (1985). Energy flow between the pelagic and benthic zones: factors controlling particulate organic matter available to an intertidal mussel bed. Can J. Fish. Aquat. Sci. 42: 1158-1165

Griffiths, C. L., King, J. A. (1979). Energy expended on growth and gonad output in the ribbed mussel Aulacomya ater. Mar. Biol. 53: 217-222

Griffiths, R. J. (1977). Reproductive cycles in littoral populations of Choromytilus meridionalis ( $\mathrm{Kr}$ ) and Aulacomya ater (Nolna) with a quantitative assessment of gamete production in the former. J. exp. mar Biol. Ecol. 30: 53-71

Griffiths, R J. (1980a). Filtration, respiration and assimilation in the black mussel Choromytnlus meridionalis. Mar. Ecol. Prog. Ser. 2: 63-70

Griffiths, R. J. (1980b). Natural tood availability and assimilation in the bivalve Choromytilus meridionalis. Mar Ecol. Prog. Ser, 3: 151-156

Hawkins, A. J. S. (1983). Metabolic strategy in the marine mussel Mytilus edulis L. Ph.D. thesis, University of Exeter

Hawkins, A J.S. (1985). Relationships between the synthesis and breakdown of protein, dietary absorption and turn- 
overs of nitrogen and carbon in the blue mussel, Mytilus edulis L. Oecologia (Berl.) 66: 42-49

Hawkins, A. J. S., Bayne, B. L., Clarke, K. R. (1983). Coordinated rhythms of digestion, absorption and excretion in Mytilus edulis (Bivalvia: Mollusca). Mar Biol. 74: 41-48

Hawkins, A. J. S., Bayne, B. L. (1984). Seasonal variation in the balance between physiological mechanisms of feeding and digestion in Mytilus edulis (Bivalvia: Mollusca). Mar Biol. 82: 233-240

Hawkins, A. J. S., Bayne, B. L. (1985). Seasonal variation in the relative utilization of carbon and nitrogen by the mussel Mytilus edulis: budgets, conversion efficiencies and maintenance requirements. Mar. Ecol. Prog. Ser 25: 181-188

Jury, M. R. (1980). Characteristics of summer wind field and air sea interactions over the Cape Peninsula upwelling regions. M. Sc. thesis. University of Cape Town, South Africa

Klumpp, D. W. (1984). Nutritional ecology of the ascidian Pyura stolonifera: influence of body size, food quantity and quality on filter feeding, respiration, assimilation efficiency and energy balance. Mar Ecol. Prog. Ser. 19: 269-284

Lucas, M. I., Painting, S., Muir, D. (1986). Estimates of carbon flow through bacterioplankton in the southern Benguela upwelling region, based on ${ }^{3} \mathrm{H}$-Thymidine incorporation and predator-free incubations. Actes de colloque, IFREMER/CNRS 3: 375-383

Lucas, M. I., Newell, R. C., Shumway. S. E., Seiderer, L. J., Bally, R. (1987). Particle clearance and yield in relation to bacterioplankton and suspended particulate availability in estuarine and open coast populations of the mussel Mytilus edulis. Mar. Ecol. Prog. Ser. 36: 215-224

Monar, I. (1972). Analysenautomat zur simultanen Mikrobestimmung von C. H und N. Mikrochim. Acta 1972: 784-806

Muir, D. G. (1986). Bacterial populations and their activity in the Benguela upwelling system. Ph. D thesis, University of Cape Town, South Africa

Muir, D. G., Seiderer, L. J., Davis, C. L., Painting, S. J., Robb, F. T (1986). Filtration, lysis and absorption of bacteria by mussels Choromytilus meridionalis collected under upwe]ling and downwelling conditions. S. Afr. J. mar. Sci. 4: $169-179$

Newell, R. C., Field, J. G., Griffiths, C. L. (1982). Energy balance and significance of micro-organisms in a kelp bed community. Mar. Ecol. Prog. Ser 8: 103-113

This manuscript was submitted to the editor
Newell, R. C., Field, J. G. (1983). The contribution of bacteria and detritus to carbon and nitrogen flow in a benthic community. Mar Biol. Lett. 4: 23-36

Seiderer, L. J., Davis, C. L., Robb, F. T., Newell, R. C. (1984), Utilization of bacteria as a nitrogen resource by kelp bed mussel Choromytilus meridionalis. Mar. Ecol. Prog. Ser 15: $109-116$

Seiderer, L. J., Newell, R. C. (1985). Relative significance of phytoplankton, bacteria and plant detritus as carbon and nitrogen resources for the kelp bed filter feeder Choromytilus meridionalis. Mar. Ecol. Prog. Ser. 22: 127-139

Stuart, V. (1982). Absorbed ration, respiratory costs and resultant scope for growth in the mussel Aulacomya ater (Molina) fed on a diet of kelp detritus of different ages Mar Biol. Lett. 3: 289--306

Stuart, V., Field, J. G., Newell, R. C. (1982). Evidence for absorption of kelp detritus by the ribbed mussel Aulacomya ater using a new ${ }^{51} \mathrm{Cr}$-labelled microsphere technique. Mar Ecol. Prog. Ser. 9: 263-271

Stuart, V., Klumpp, D. W. (1984). Evidence for food resource partitioning by kelp bed filter feeders. Mar. Ecol. Prog. Ser. 16: $27-37$

Velimirov, B., Field, J. G., Griffiths, C. L., Zoutendyk, P. (1977). The ecology of kelp bed communities in the Benguela upwelling system: analysis of biomass and spatial distribution. Helgoländer wiss. Meeresunters. 30: 495-518

Widdows, J. (1978). Combined effects of body size, food concentration and season on the physiology of Mytilus edulis. J. mar biol. Ass. U. K. 58: 109-124

Widdows, J., Fieth, P., Worral, C. M. (1979). Relationships between seston, available food and feeding activity in the common mussel Mytilus edulis. Mar. Biol. 50: 195-207

Widdows, J., Donkin, P., Salkeld, P. N., Cleary, J. J., Lowe, D. M., Evans, S. V., Thomson, P. E. (1984). Relative importance of environmental factors in determining physiological differences between two populations of mussels (Mytilus edulis). Mar Ecol. Prog. Ser. 17: 33-47

Wildish, D. J., Kristmanson, D. D. (1984). Importance to mussels of the benthic boundary layer. Can. J. Fish. Aquat. Sci. 41: $1618-1625$

Wulff, F. V., Field, J. G. (1983). Importance of different trophic pathways in a nearshore benthic community under upwelling and downwelling conditions. Mar. Ecol. Prog. Ser 12: $217-228$

Manuscript first received: December 7, 1988

Revised version accepted: March 30, 1989 